\title{
The best way to skin a cat: product consumption versus direct observation for monitoring hand hygiene performance
}

\author{
AJ Stewardson", H Attar, S Touveneau, W Zingg, S Longet-Di Pietro, N Vernaz, D Pittet, H Sax, \\ Members of the Infection Control Program \\ From International Conference on Prevention \& Infection Control (ICPIC 2011) \\ Geneva, Switzerland. 29 June - 2 July 2011
}

\section{Introduction / objectives}

Direct observation (DO) and alcohol-based handrub (ABHR)Â consumption per 1000 patient days Â (AC) are used to monitor hand hygiene $(\mathrm{HH})$ performance in healthcare, and are increasingly utilised as quality indicators, sometimes for external benchmarking. We investigated the common assumption that there is a direct correlation between these two measures.

\section{Methods}

For Â the baseline period of a cluster-randomized trial regarding multimodal hand hygiene promotion at a 2200 bed tertiary-care facility, 8 validated infection control nurses performed DO using the WHO 'My 5 Moments' method in 65 non-ICU acute care wards for 15 months from April 2009.ÂA ABHR usage and patient days per ward were extracted from hospital databases to calculate AC over the same period. Linear regression was used to determine the correlation between these two variables, with each unit's compliance weighted for the number of $\mathrm{HH}$ opportunities observed.

\section{Results}

DO capturedÂ $4601 \mathrm{HH}$ opportunities and $2962 \mathrm{HH}$ actions, $99 \%$ of which involved ABHR use. HH compliance in individual wards ranged from $\hat{A} 38.2 \%$ to $\hat{A}$ 90.2\% with a mean of $64.6 \%,(\mathrm{CI} 95,62.0-67.2)$. $\hat{A}$ A total of 13,939 litres $\hat{A}$ of ABHR was consumed during 459,917 patient days. AC ranged from 10.8 to $62.0 \mathrm{~L} / 1000$ bed days with a mean of 31.4 (CI95, 28.5-34.4). Both $\mathrm{HH}$

University of Geneva Hospitals, Geneva, Switzerland compliance and $\mathrm{AC}$ were normally distributed, with a weak and non-significant correlation $(\mathrm{r}=0.13 ; P=0.21)$.

\section{Conclusion}

In this setting, DO and AC are not significantly correlated, complicating efforts to monitor $\mathrm{HH}$ performance. Further investigation should examine which is a better indicator for relevant clinical outcomes such as microbial colonisation and healthcare-associated infection.

\section{Disclosure of interest}

None declared.

Published: 29 June 2011

doi:10.1186/1753-6561-5-S6-P103

Cite this article as: Stewardson et al:: The best way to skin a cat:

product consumption versus direct observation for monitoring hand hygiene performance. BMC Proceedings 2011 5(Suppl 6):P103.

Submit your next manuscript to BioMed Central and take full advantage of:

- Convenient online submission

- Thorough peer review

- No space constraints or color figure charges

- Immediate publication on acceptance

- Inclusion in PubMed, CAS, Scopus and Google Scholar

- Research which is freely available for redistribution

Submit your manuscript at www.biomedcentral.com/submit
C Biomed Central

\section{Biomed Central}

(c) 2011 Stewardson et al; licensee BioMed Central Ltd. This is an open access article distributed under the terms of the Creative Commons Attribution License (http://creativecommons.org/licenses/by/2.0), which permits unrestricted use, distribution, and reproduction in any medium, provided the original work is properly cited. 